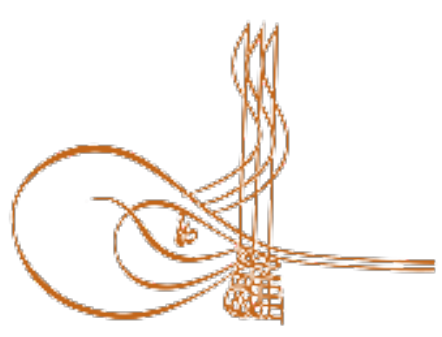

www.turkishstudies.net/language
Turkish Studies - Language and Literature

eISSN: $2667-5641$

Research Article / Araștırma Makalesi

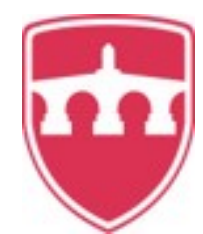

INTERNATIONAL

BALKAN

UNIVERSITY

Sponsored by IBU

\title{
Bir Arzıhal/Hasbihal Şairi Şeref Hanım ve Divanı'nın Edebi Türler ve Tarzlar Bakış Açısıyla Değerlendirilmesi
}

\author{
A Chat Poet Şeref Hanım and Review Her Book: Literary Genres and Style From \\ Perspective
}

Abdülkadir Kızıltaş*

\begin{abstract}
Literary text analysis is basically shaped around three parameters: form, content and style. However, at the analysis of classical Turkish literature texts, It cannot be said that the literary texts in question have been examined in detail in the context of the genre and style. In fact, each verse, couplet, bend, each verse in divan form; in prose works and mesnevi, each section can be expressed in different genres and styles. In our opinion, the meaning world of classical Turkish literature will be examined by the literary genre and genre perspective from the piece to the whole, and the data obtained can be revealed a little more. One of these independent works to be examined is the Divan of Şeref Hanım. Şeref Hanım, one of our 19th century women poets, has written poems in almost every verse as well as giving examples of genres and styles in her divan. According to classic Turkish literatüre researches are mostly done through texts and existing texts are review either from the nomenclature of the poets or from the research, all classifications and finding in this study will be take off a general view of the mentioned species. With this view point, in this study, literary genres and styles in Şeref Hanım Divan were determined on the basis of verse units such as verse, couplet and bend, and all the data obtained were recorded.
\end{abstract}

Structured Abstract: Şeref Hanım is one of the three most important female poets of the XIX. century; other important female poets of this century are Leyla Hanım and Adile Sultan. Şeref Hanım, with her simple language, strong verse technique has written pathetic merstars, naat and müncats, ghazane ghazals and kasides. Also she brought exemplary poetry to almost every form and style of classical poetry. Şeref Hanım's Divan is a very rich book in terms of content style. It is seen that sometimes more than one subject is covered in a poem. Sometimes more than one style is encountered in a line. We should only state that this does not lead to confusion in her poetry. Unlike this situation is pointing that literary genres can work harmony. On the other hand this diversity and wealth in his book will be conduce to the emergence of new species. Divan

\footnotetext{
* Arş. Gör. Dr., Bingöl Üniversitesi, Fen-Edebiyat Fakültesi, Türk Dili ve Edebiyatı Bölümü, Eski Türk Edebiyatı Anabilim Dalı

Ress. Assit. Dr., Bingol University, Faculty of Arts and Science, Department of Turkish Language and Literature, Old Turkish Literature

ORCID 0000-0002-6261-9496

kiziltas_27@hotmail.com
}

Cite as/ Atıf: Kızıltaş, A. (2020). Bir arzıhal/hasbihal şairi Şeref Hanım ve Divanı'nın edebi türler ve tarzlar bakış açısıyla değerlendirilmesi, $\quad$ Turkish Studies - $\quad$ Language, $15(1), \quad 305-324$. https://dx.doi.org/10.29228/TurkishStudies.37343 Received/Geliş: 13 September/Eylül 2019

Accepted/Kabul: 24 March/Mart 2020

Copyright à INTAC LTD, Turkey

Checked by plagiarism software

Published/Yayın: 30 March/Mart 2020

CC BY-NC 4.0 
of Şeref Hanım is very rich in literary genre and style. The dominant item in her divan is chat. Whatever the subject and style of expression of the book, chat style is dominant in all of her poems. İnformation about the subject and the form of expression are generally recorded in encyclopedias and literary dates or in the mix of recorded information in research studies. That's why in this article that Şeref Hanım's Divan was thoroughly scanned with this viewpoint and the data obtained were carefully recorded will be useful in redefining literary genres. İn this context, literary genres must record not only in independent poems, but also even at the level of verses, fours and clauses. Because some literary genres can be seen as the dominant item in individual books. And sometimes a poem can be written in many topics and formats. This article evaluates Şeref Hanım's Divan under two titles that including literary genre and literary style. The items evaluated under the title of literary style are as follows: Chat, prayer, criticism, brag, asking for help, apologize, puzzle, praise, advice, assume, complaint, curse, thank god, history, greeting, thanks. On the other hand the item evaluated under the title of literary genre are as follows: Bahariye (poems containing the depictions of spring), besmelename (poems start by the name of creator), firakname (poems on the subject of separation), kudumiye (poems a gift to a state eld), mektup (letter), mersiye (poems lament after a dead person), mevlid (poems describing the birth of the Dear Mohammed), naat (poems praising Dear Mohammed), sakiname (poems praising the drik and the bartender), salname (poems yearly), tahlil (poems using the word tawhit as a redif). All the literary genres and literary style mentioned have been carefully recorded. If we summarize that, literary text analysis is basically shaped around three parameters: form, content and style. However, at the analysis of classical Turkish literature texts, It cannot be said that the literary texts in question have been examined in detail in the context of the genre and style. In fact, each verse, couplet, bend, each verse in divan form; in prose works and mesnevi, each section can be expressed in different genres and styles. In our opinion, the meaning world of classical Turkish literature will be examined by the literary genre and genre perspective from the piece to the whole, and the data obtained can be revealed a little more. One of these independent works to be examined is the Divan of Şeref Hanım. Şeref Hanım, one of our 19th century women poets, has written poems in almost every verse as well as giving examples of genres and styles in her divan. In this study, literary genres and styles in Şeref Hanım Divan were determined on the basis of verse units such as verse, couplet and bend, and all the data obtained were recorded. İ this study used, 2011 edition of the work of Mehmet Arslan prepared. Also, first abbreviation verse, (.) first number after the sign the number from which the quote wase mad eline number, (/) first number after the sign couplet number express in poetry quotes. İn this article, Metin Akkuş's "Klasik Türk Şiirinin Anlam Dünyası: Edebi Türler ve Tarzlar" book that gives detailed information on the subject used in some definitions of literary genres and literary style. As known, classic Turkish literatüre researches are mostly done through texts. Existing texts are review either from the nomenclature of the poets or from the research. According to this the data we obtained by scanning Şereh Hanım's Dıvan from beginning to end will be usefull in redefining and classify literary genres and literary styles. It will be also help identify new literary genres and literary styles.

Keywords: Classical Turkish Poetry, Divan, Şeref Hanım, Literary genres, Literary Styles.

Öz: Edebi metin çözümlemeleri biçim, muhteva ve üslup olmak üzere temelde üç parametre etrafinda şekillenmektedir. Fakat klasik Türk edebiyatı metinleri üzerine yapılan tahlil, şerh, analiz vb. gibi çeşitli çalışmalarda, söz konusu edebi metinlerin türü (metnin ne anlattığı/muhtevası) ve tarzı (metnin nasıl anlattığı, ifade biçimi, üslubu) bağlamında ayrıntılı bir şekilde incelendiği söylenemez. Öyle ki, divanlarda her bir mısra, beyit, bend, her bir nazım şekli; mensur eserlerde ve mesnevilerde ise her bir bölüm farklı tür ve tarzla ifade edilebilmektedir. Kanaatimizce klasik Türk edebiyatının anlam dünyası, bünyesinde barındırdığı müstakil eserlerin parçadan bütüne doğru edebi tür ve tarz bakış açısıyla incelenip, elde edilen verilerin kayda girilmesiyle biraz daha gün yüzüne çıkabilecektir. Bu bağlamda türler ve tarzlar sadece müstakil şiirlerde değil, aynı zamanda bendler, kıt'alar ve hatta şiirin en küçük nazım birimi kabul edilen mısralar seviyesinde bile incelenmeli ve elde edilen veriler kayda girmelidir. İncelemeye alınması gereken eserlerden biri de Şeref Hanım Divanı'dır. XIX. yüzyıl kadın şairlerimizden olan Şeref Hanım, divanında, Klasik Türk şiirinin hemen her nazım şeklinde şiir kaleme almış olmasının yanı sıra, birçok tür ve tarzın örneklerini vermeyi de ihmal etmemiştir. Klasik Türk edebiyatı araştırmaları büyük oranda metinler üzerinden yapıldığına, ayrıca türlerin tespiti ve tasnifi konusunda ortak bir muhtevaya sahip ve belli bir yekun oluşturan şiirlerin benzeşen yönlerini tespit edip belirtmek o türü tanımlamak olduğuna göre, bu çalışmada yapılacak olan bütün tasniflemeler ve bulgular aynı zamanda bahsi geçen türlerin ya da tarzların genel bir görüntüsünü çıkarmak olacaktır. Bu bakış açısıyla Şeref Hanım Divanı'ndaki edebi tür ve tarzlar 
mısra, beyit ve bend gibi nazım birimleri esas alınarak tespit edilmiş, ulaşılan bütün veriler örneklendirilerek kayda alınmıştır.

Anahtar Kelimeler: Klasik Türk Şiiri, Divan, Şeref Hanım, Edebi Türler, Edebi Tarzlar.

\section{Giriş}

Şeref Hanım, sade dili, kuvvetli nazım tekniğiyle acıklı mersiyeler, naat ve münacatlar, aşıkane gazel ve kasideler kaleme almış, böylece klasik şiirin hemen her nazım şekline ve türüne örnek manzumeler kazandırmış, XIX. yüzyılın en önemli üç kadın şairinden biridir. Bu yüzyılın önemli diğer kadın şairleri ise Leyla Hanım ve Adile Sultandır. (Arslan, 2011: 24) Edebi tür ve tarz açısından oldukça zengin olan Şeref Hanım Divanı'nda hakim tarz olarak arzıhal/hasbihal ön plana çıkmaktadır. Kullanılan nazım şekli, tercih edilen tür ya da anlatım biçimi (tarzı) ne olursa olsun, şiirlerinin hemen hepsinde bir arzıhal/hasbihal tarzı kendini hissettirmektedir. Aşağıdaki beyit ise divanın hangi türler ve tarzlar bakımından zengin olduğunu belirtmesi açısından önemlidir.

\section{Na't u mersiye münâcât u sitâyişlerimi}

Sebeb-i mağfiret it zîver-i dîvân eyle (G.232/2) ${ }^{1}$

Tür ve tarzla ilgili bilgiler genellikle ansiklopedilerde ve edebiyat tarihlerinde; özel olarak da araştırma çalışmalarında kayıtlı olan bilgilerin karması olduğundan, (Akkuş, 2006: 1) Şeref Hanım Divanı'nın ilk mısrasından son mısrasına kadar tür ve tarz bakış açısıyla taranarak önemine göre beyit/bend bazında örneklendirmelerin yapıldığı, örnek teşkil edebilecek diğer verilerin ise ihtimamla kayda alındığı bu çalışmamızın, edebi tür ve tarzların yeniden tanım, tasvir ve gruplandırılmasında faydalı olabileceği kanaatindeyiz.

$\mathrm{Bu}$ bağlamda türler ve tarzlar sadece müstakil şiirlerde değil, aynı zamanda bendler, kıt'alar ve hatta şiirin en küçük nazım birimi kabul edilen mısralar seviyesinde bile takip edilmeli ve kayda girmelidir diye düşünüyoruz. Çünkü yer yer müstakil kitap ve risalelerde bazı tür ve tarzlar hakim öğe olarak kendini gösterebilirler. Bazen de bir şiir birçok tür ya da tarz etrafında kaleme alınmış olabilir. Aşağıda örneğini vereceğimiz müsemmen nazım şeklinde, mersiye türünde kaleme alınmış şiirin 5. bendinin hemen her mısrasının farklı bir tarzı karşılaması buna güzel bir örnek olarak gösterilebilir. Bu bendin 7. mısrasında fahriye ve tahmid olmak üzere iki farklı tarzın iç içe geçmiş olduğu görülebilir.

$$
\begin{aligned}
& \text { Ne 'akla uydun ey İbni Ziyâd ey kâfir-i murdar } \rightarrow \text { hasbihal } \\
& \text { Hücûm itdin o şâha bir takım kelbe olup serdâr } \rightarrow \text { hiciv } \\
& \text { Nice el sundı yâ Şimr-i la 'în ü b̂̀-edeb gaddâr } \rightarrow \text { tel'în/beddua } \\
& \text { Degil midir o gerden bûse-gâh-ı Ahmed-ı Muhtâr } \rightarrow \text { medhiye } \\
& \text { Nasıl kan ağlayup yâd itmeyim ol demleri her bâr } \rightarrow \text { tazallüm/şikayet } \\
& \text { Onulmaz işler ölünce yürekten nice yârem var } \rightarrow \text { tazallüm/şikayet } \\
& \text { Bi-hamdillâh muhibb-i Hazret-i Âl-i 'Abâ'yım ben } \rightarrow \text { fahriye-tahmid } \\
& \text { Ezelden hânedân-ı Mustafa'ya cân-fedâyım ben } \rightarrow \text { fahriye (Msm.1/5) }
\end{aligned}
$$

Metin Akkuş, Klasik Türk Şiirinin Anlam Dünyası adlı eserinde yukarıda verdiğimiz örneği destekler nitelikte şunları kaydetmektedir: "Türlerin yalnızca bağımsız yapılarda aranamayacağı da

\footnotetext{
${ }^{1}$ Bu çalışmada, Prof. Dr. Mehmet Arslan'ın hazırlamış olduğu eserin 2011 baskısı kullanılmış, alıntılanan metinlerde söz konusu çalışmadan yararlanılmıştır. Ayrıca şiir alıntılarında ilk kısaltma nazım şeklini, (.) işaretinden sonraki ilk rakam alıntının yapıldığı nazım şekli numarasını, (/) işaretinden sonraki rakam beyit veya bend numarasını, varsa (-) işaretinden sonraki rakam ise beyit veya bend aralığını ifade etmektedir.
} 
mevcut örneklerden anlaşılmaktadır. İngiliz edebiyatında ağıtın (elegy) ikili mısralardan dörtlü mısralar haline dönüştürülmesi gibi, Klasik Türk edebiyatında da mısra seviyesinden başlayarak bağımsız eser ölçüsüne ulaşıncaya kadar edebi türlerin gelişimi takip edilmelidir. Bu işe divanlardaki ferdlerden başlayıp bağımsız eser halindeki mesneviye kadar ulaşılabilir." (Akkuş, 2011:18)

Şeref Hanım Divanın'da tespit edilen edebi tarzlar ve türler şunlardır ${ }^{2}$

I- Edebi Tarzlar (Anlatım Biçimleri)

1. Arzihal/Hasbihal

Arzıhal/hasbihal, söyleşme, sohbet etme, dertleşme ne halde olduğunu anlatma anlamlarına gelmektedir. Edebiyatta ise şairlerin samimi bir dille bazen ikinci şahıslarla, bazen kişileştirme yoluyla felek, rüzgar, kalem, gam, gönül gibi somut ya da soyut kavramlarla, bazen de bizzat ya kendi kendisiyle konuşması/söyleşmesi şeklinde olan bir tarz adıdır. Divanda Şeref Hanım, sevgilisi, gönlü, kalemi, gözü, rüzgar ve felek ile sohbet etmektedir. Bu sohbet bazen nasihat etme, çoğu zaman da yerinme, sızlanma, şikayet gibi tarzları ifade eden tazallüm ile düzenlenmektedir. Divandaki hasbihallerin birçoğu tazallüm/şikayet alt görünümüne/tarzına sahiptir.

Senin ey münkir-i hod-bîn billâh medh ü zemminden

Yapılmaz hâtırı aslâ sıkılmaz cânı dervî̧sin (K.11/2)

Dil-i pûlâdını nerm eylemediyse ey şûh

Eser-i âhımı sen mermere sor sorma bana (G.3/2)

Hak-bîn isen ey dil gözet âdâb-ı hakîkat

Ashâb-ı mecâz olma ol erbâb-ı hakîkat ( G.22/1)

Divanda şairin mahlasını kullandığı beyitlerin neredeyse tamamı arzıhal/hasbihal tarzını yansıtmaktadır. Şair, mahlasını kulladığı beyitlerde genellikle nefsiyle sohbet etmektedir.

Neyleyim 'aksine devr itdi felek şimdi Şeref

Ol ne demlerdi dile 'arz-ı cemâl eylerdi yâr ( G.40/7)

Sana müstelzem-i şevk-i dü-bâlâ idi ey hûnî

'aceb hâtırda mı terk-i ser ü cân itdiğim demler (G.42/3)

Yâr ile itdikleri zevki bilürsen saklama

Ey sabâ ben zümre-i ağyârdan aldım haber ( G.46/3)

İdersin herkes ile her gice sen zevk u şevk ammâ

Şeref bir lahza sensiz ey meh-i tâbânım eglenmez ( G.64/5)

\footnotetext{
${ }^{2}$ Tür ve tarzların bazı tanımlamalarında konuyla ilgili ayrıntılı bilgi veren (Metin Akkuş, Klasik Türk Şiirinin Anlam Dünyası: Edebi Türler ve Tarzlar: Erzurum 2008 ) kaynağı kullanılmıştır.
} 
Ta'cîz itme yârî didim 'arz-ı hâl ile

Tutmaz nasîhatım dil-i âvâre neyleyim ( G.135/5)

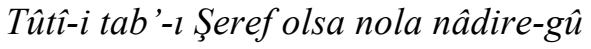

Bâ is-i her sühânım sensin efendim sensin (G.149/5)

Eylesem nola ciger kanıyla tahrîr ü beyân

Hem Şeref'den hem gönülden çekdiğim derdi hemân

Gâh şarkı gâh gazelle böyle her vakt ü zamân

'Arz-ı hâl itmek cenâb-ı yâre kârımdır benim (Ş.6/5)

Divanda geçen diğer arzıhal/hasbihal kayıtları şunlardır: (Mh.1/1-5), (Th.1/1 ),( Th.4/5 ), ( Th.5/1-4 ), (Th.11/1-5 ), (Th.12/1-5 ), (Ms.2/2 ), ( Ms.5/1-12 ), ( Ms.15/1-12 ), ( Ts.2/1 ), ( G.4/15 ), ( G.5/1-5 ), ( G.6/1-5 ), ( G.15/1-6 ), ( G.16/3-5 ), ( G.17/1-5 ), ( G.18/1-5 ), ( G.27/2-3 ), ( G.34/2 ), ( G.35/1 ), ( G.39/1-2), ( G.41/1-5 ), ( G.42/1-5 ), ( G.44/1-6 ), ( G.47/1-7 ),( G.49/1-5 ), ( G.50/1-5 ), ( G.51/1-5 ), ( G.52/1-5 ), ( G.53/1-5 ), ( G.54/1-5 ), ( G.56/1-7 ), ( G.62/1-5 ), ( G.63/1-5 ), ( G.67/6 ), ( G.71/1-5 ), ( G.73/1-5 ), ( G.83/4 ), ( G.86/1 ), ( G.87/2 ), ( G.91/1-7 ), ( G./1-5 ), ( G.93/1-5 ), ( G.94/1-7 ), ( G.95/1-5 ), ( G.96/1-6 ), ( G.97/1-5 ), (G.101/1-5 ), ( G.107/1-5 ), ( G.108/1-5 ), ( G.111-1-5 ), ( G.112/1-5 ), ( G.113/1-5 ), ( G.114/1-5 ), ( G.115/1-5 ), ( G.118/1,4 ), ( G.124/1-5 ), ( G.126/1-9), ( G.133/2 ), ( G.134/1-9), ( G.148/1-5 ), ( G.149/1-5), ( G.152/1-5 ), ( G.157/1-5 ), ( G.159/1-7 ), ( G.164/1-9), ( G.166/1-5), ( G.168/1-5 ), ( G.170/1-5 ), ( G.173/1-5 ), ( G.171/4 ), ( G.177/3-4 ), ( G.179/1-7 ), ( G.186/1-5 ), ( G.189/1-6 ), ( G.190/1-5 ), ( G.191/1 ), ( G.192/1-5 ), ( G.193/4 ), ( G.203/1-5 ), ( G.204/1-5 ), ( G.206/3-5 ), ( G.207/1-5 ), ( G.208/1-5 ), ( G.214/2 ), ( G.215/1-5 ), (G.216/3 ), ( G.217/1-2 ), ( G.236/1-5 ), ( G.237/1 ), ( G.238/1 ), ( G.235/1-5 ), ( G.240/1-5 ), ( G.242/3,5 ), ( G.243/1,4-5 ), ( G.244/1-5 ), ( G.245/5 ), ( G.247/3-5 ), ( G.248/1-5 ), ( G.249/1-5 ), ( G.250/1-5 ), ( M.1/1-5 ), ( S..3/1-4 ), ( S..7/1-5 ), ( Ş.9/1-5 ), ( Ş.11/1-4 ), ( Ş.12/1-5 ), ( Ş.13/1-4 ), ( Ş.17/1-3 ), ( Ş.20/1-4 ), ( Ş.24/1-4 ), ( Ş.26/1-4 ), ( S..28/1-4 ), ( Ş.29/1-5 ), ( Ş.33/1-5 ), ( Ş.34/1-5 ), ( Ş.35/1-5 ), ( Ş.38/1-5 ), ( Ş.40/1-5 ), ( Kt.37/1-2 ), ( Kt.40/1-2 ), ( Kt.47/1-2 ), ( Kt.49/1-2 ), ( Kt.50/1-2 ), ( Kt.52/1-2 ), ( Kt.53/1-2 ), ( Kt.63/1-2 ), ( Kt.80/1-2 ), ( Kt.87/1-2 ), ( Kt.90/1-2 ), ( Kt.91/1-2 ), ( Kt.99/1-2 ), ( Kt.100/1-2 ).

\section{Dua/Temenni/Niyaz}

Şeref Hanım Divanı'nda 20. kaside bir bütün olarak duaname/niyaznameye örnek teşkil etmektedir. 'Asker-i İslâm redifli bu şiirde ilk beyitten son beyite kadar şair İslam ordusunun muzafferiyeti için dualar etmektedir. Bu şiirde, Şeref Hanım sosyal duyarlılığ 1 yüksek, vatanperver bir kadın görünümü sergilemektedir.

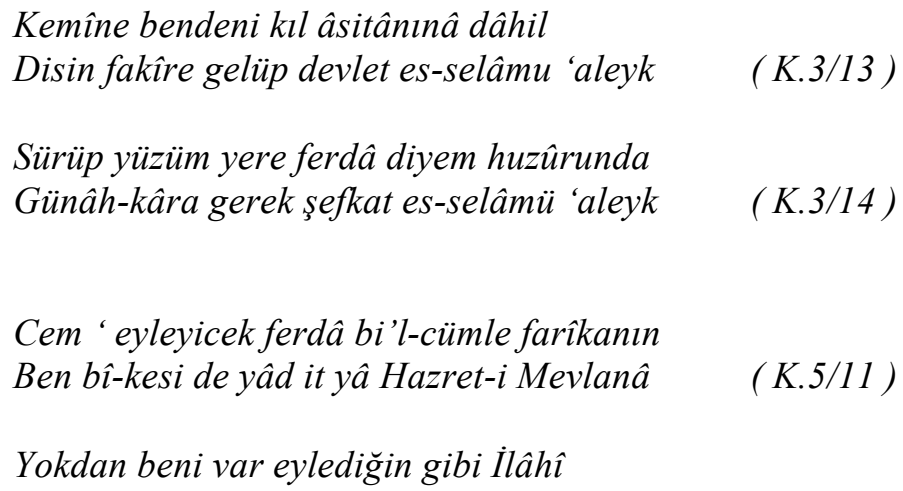

www.turkishstudies.net/language 
Halk it düşeyim pâyına bir mürşid-i kâmil

Çeksin beni tutsun elimi râh-ı necâta

İmdâd ile irşâd ide bir rehber-i fâzıl ( G.103/5-6)

Kerem-kârâ 'azîz başın içün târîhlerlerim 'arz it

Demidir hâk-i pây-i Hazret-i 'Abdü'l-Mecîd Hân'a

Divanda geçen diğer dua/temenni/niyaz kayıtları ( K.16/38-39), ( Ts.2/1-5 ), ( Kk.1/1-5 ), ( Kk.1/1-12 ), ( Kk.1/1-7)

\section{Hicviye}

Hiciv, Arapça'da bir kişiyi şiir veya nesir yoluyla yerme/eleştirme anlamına gelmektedir. Klasik Türk şiirinde yergi vb anlatma biçimlerinin genel adını ifade etmektedir. Divanda yergi tarzı şairin kendini ve çoğunlukla sevgilisini eleştirdiği beyitlerde görülmektedir.

Bilmezem gayri sana 'âşıkım âlemde beni

Sanma kendin gibi her gördüğ̈̈me yâr olurum ( G.127/6)

Bî-vefâlık 'âdet-i dîrînesidir dilberin

Lîk ey zâlim bu rütbe kîne-hâr olmak neden

Şerh eyleme bîhûdedir ahvâlimi yâre

Bin böyle gazelle Şeref ifhâm idemezsin ( G.156/5)

Şeref yok sende zerre kâbiliyyet gün gibi zâhir

Ne ümmîd ile bilmem 'arz-ı 'irfân itmek istersin ( G.161/1-6)

Divanda geçen diğer hiciv kayıtları: ( G.158/1-3 ), ( G.169/1-5 ), ( G.210/7 ), ( Ş.1/4 ).

\section{Fahriye}

Övünme, büyüklenme anlamlarına gelmektedir. Klasik Türk şiirinde fahriye, şairlerin kendi özelliklerinden bahsederek övündükleri manzumelere verilen addır. Divanda şair, peygambere ümmet olması, sadıklığı, doğru sözlü, dürüst ve vefalı olması gibi özellikleriyle övünmektedir.

Bi-hamdillâh Muhammed Mustafâ gibi şehen-şâha

Bir ednâ ümmetim ki cihânda iftihârım var (G.60/2)

Kays u Ferhâd bana 'aşkda emsâl olmaz

Bülbül-i dil-şüde pervâneye hem-hâl olmaz (G.61/1)

Sâdıkım Hak da bilür 'aşkımı senden gayri

Bir şehe bende vü bir kimseye 'âşık değilim

Râst-gûyum sözi bir söylerim itmem inkâr

Hamdü-lillâh ki iki yüzli münâfik degilim (G.124/3-4) 
Sâbitim 'ahdimde olmam gayri şâhın bendesi

Bir zamânda kesr-i peymân itmedim itmem yine (G.205/5)

Hakîkat sadâkat mürüvvet vefâ

Benimçün yaratmış Cenâb-ı Hudâ

Selefde halefde efendim eger

Şeref gibi bende bulursan salâ (Kt.12/1-2)

Divanda geçen diğer fahriye kayıtları şunlardır: ( G.1/1-7 ), ( G.20/1 ), (G.60/1-8 ),

( G.205/1-7), ( Kt.13/1-2 ).

\section{5. İstimdad}

İstimdad, bir din ya da devlet büyüğünden yardım isteme, meded umma tavrını yansıtan şiirlerin genel anlatım biçimidir. Aşağıda örneğini vereceğimiz mersiye türünde kaleme alınmış 14. müseddesin son bendi istimdad tarzına örnektir. Şair bu örnekte Hz. Ali'den yardım istemektedir. Divanda ayrıca Mevlânâ'dan, Abdulkadir Geylânî'den, Şeyh Nûreddîn'den, Veysü’lKarenî’den, Seyyid Rufầ'̂̀'den, dört halifeden, Padişah Abdülmecid'ten istimdadlarda bulunulmuştur.

Olunuz ferdâ meded-hâh-ı Şeref

İtdim ‘ömr ü vakti bîhûde telef

Ehl-i mahşer cem 'olunca saf-be-saf

Bulayım râh-ı necâta bir taraf

El-amân Sâkî-i Kevser Murtazâ (Ms.14/6)

Divanda geçen diğer istimdad kayıtları şunlardır: ( K.5/1-12 ), ( Mr.5/1-7 ), ( Mh.6/1-5 ),

( Ms.7/1-7) (Ms.8/1-8) ( Ms.9/1-6 ) ( Ms.13/1-7) ( Kk.1/1-2 ).

\section{6. İ 'tizâr}

Özür dilemek manasına gelmektedir. Edebiyatımızda özür dileme tarzına örnek olarak gösterilebilir ve bu içerikteki metinler i'tizâriye olarak değerlendirilebilir. Şair bizzat bu kelimeyi kullanarak birçok defa çeşitli vesilelerle, farklı kişi ve makamlara özürlerini sunmaktadır.

Olup mağrûr-ı 'afv öyle kerem-kârânı itdim yâd

Hemân şimden girü cümle kelâmım i ‘tizâr

Sür derger-i niyâza yüzün i'tizâr eyle

'Arz it biraz da kasd-ı dil-i pür-melâleti (K.17/35)

Düşüp ümmîd-i 'afvile der-i ihsânına gönlüm

Bilüp cürm ü kusûrın pây-mâl-i i 'tizâr oldı

Tekdîr ile memnûn kul itdikçe kabâhat

Öldürdi beni âh efendim bu nedâmet

Ben itdiğime mu'terifem sen de nihâyet

'Afv eyle 'azîz başın içün cürm ü günâhım

Besdir ıtnâb-ı sühân ey hâme-i mu 'ciz-beyân 
I'tizâr eyle biraz da 'arz-ı hal eyle hemân (Ms.4/10)

Divanda geçen diğer i’tizâriye kayıtları şunlardır: ( G.59/4 ), ( G.60/8 ), ( Ş.15/1-4 ).

7. Lugaz

Bilmece anlamındadır. Edebiyat ise manzum bilmecelere verilen addır. Divanda 4 adet lugaz bulunmaktadır.

Ol nedir kim şekl ü etvârl 'acîb

Levni birkaç rengden almış nasîb ～(L.2/1)

\section{Medhiye}

Övme anlamına gelmektedir. Edebi terim olarak, bir kimseyi veya bir kişiyi övmek için yazılmış şiir anlamıyla divan edebiyatında bir anlatım tarzına ad olmuştur.

Cedd-i cenâb-ı pîrleri Mahbûb-ı Kibriyâ

Olmaz mı bendesi bu cihân Kâdirîler'in (K.8/2)

Her tarîkin eylemem inkâr feyz ü şevkini

Lîk başka tarz u sûretdir gürûh-ı Mevlevî

Divanda geçen diğer mehdiye kayıtları şunlardır: Peygamber methiyesi ( K.3/1-11 ), ( K.4/1-17), ( K.6/1-4, K.6/9-16 ); Mevlevilik ve Mevlana övgüsü ( K.7/1-8,11-18 ); Kadirilerin övgüsü ( K.8/1-13, 15-18 ); Yazıc1zade övgüsü, ( K.9/1-10,12-13,16-18 ), ( K.10/1-4,6-10, ); dervişlerin övgüsü ( K.11/1-13 ), diğer ( Tb.2/2-4, 24-25 ), ( G.199/1-2,5 ), ( Ş.23/1-5 ).

\section{Nasihatname}

Ögüt verme anlamında edebi metinlerde bir tarz adıdır. Şair, şiirlerinde müntesibi veya muhibbi olduğu kanaat önderleri, din ulularının yolunu öğütlemektedir.

Kanadı altına gir sâyesinde olasın sâlim

Hümâ-yı lâne-i nahl-i cinândır Yazıcl-zâde

$(K .9 / 14)$

Devrâna gir de dinle nedir mazhar u kudûm

Kem-ter gulâmı ol bul amân Kâdirîler'in

$(K .8 / 14)$

Olma âzürde sakın gerdişs-i baht-ı dûna

Tesliyet vir bu rumûz ile dil-i mahzûna

Mâl ile irse kişi mertebe-i Kârûn'a

Pây-mâl olmada âhir sitem-i gerdûna

Pâdişâh ile gedâsı hele yek-sân ancak (Th.3/4)

Çık aradan sen yed-i kudretdedir her hayr u şer

Turkish Studies - Language, 15(1) 
Çekme tedbîr-i umûr içün 'abes yere keder

Kîl ü kâl ile sakın evkâtın itdirme güzer

Var mı Eflâtûn yâ Mecnûn diseler zarar

Dost mehdinden ne hâsll zemm-i düşmenden ne gam

Fârig u âzâdeyim birdir yanımda medh ü zem (Ts.3/2)

Divanda geçen diğer nasihat kayıtlar şunlardır: Tehlil metninde geçen nefse uymamak ve inancı sağlamlaştırmak gerektiği ( K.1/7-8), "ney dinle, sikkesini başa vur, altın ol, hırkasına sarıl", ifadeleriyle Mevlana'ya uymak gerektiği ( K.6/5-6,8), ( K.6/ 17-18 ), Mevleviliği tavsiye ( K.7/910 ), ( K.9/11,14-15 ), Ahmed-i Bî-cân'a uymak gerektiği ( K.11/17 ), diğer (Th.1/6 ), ( Th.5/5 ), ( Th.6/3-6 ), ( Th.7/1-7 ), ( Th.8/4 ), (Th.9/1-4), ( Th.13/1-4 ), ( G.27/6 ), ( G.69/2 ), ( G.70/3-4 ), ( G.123/1-5 ), ( G.156/1-4 ), ( G.246/1-5 ), ( Kt.34/1 ), ( Kt.83/1-2 ), Divanda 6. tesdis ilk bendinden, son bendine kadar nasihat tarzını örneklendirmektedir.

10. Şarkı

Divanda 42 adet "şarkı" başlıklı manzuma bulunmaktadır.

\section{Tadadiye}

Birer birer sayma, dökme anlamlarına gelmektedir. Divanda on iki imamın, dört halifenin ve Abdülmecid dönemi devlet adamlarının isimlerinin sıralandığı üç adet şiir bulunmaktadır. Edebiyatımızda örneklerine rastladığımız bu şiirlere bir edebi tarz adını ifade edecek şekilde "tadadiye" denilmesi önerilebilir. Aşağıdaki gazel, "tadadiye" tarzını farklı türlerde yazılmış şiirler içinde de rahatlıkla görebileceğimiz anlamına gelmektedir.

Felekden 'âliyim burc-ı dile pertev-nisârım var

On iki mâh ile bir âfitâb-ı tâb-dârım var

Bi-hamdillâh Muhammed Mustafâ gibi şehen-şâha

Bir ednâ ümmetim iki cihânda iftihârım var

Ne bâkim var Yezîld-i nâ-be-kâra eylerim la 'net

'Aliyyü'l-Murtazâ nâmında sâhib-Zü'l-fekâr'ım var

Hasan ile Hüseyn'in 'aşkına olmak için kurbân

Şıtâbânım ezelden cân ile kavl ü karârım var

Zihî devlet ki Zeynü'l- 'Âbidîn ü Bâkır u Sâdık

Efendimdir kemîne bendeyim özge vakârım var

Penâhım Kâzım u Mûsâ Rızâ'dır minnet Allah'a

Der-i vâlâlarına intisâba iktidârım var 
Takî ile Nakî'dir pîşvâmı hamdü-lillah kim

Mu'înim 'Askerî hem Mehdi-i 'âlî-tebârım var

Gönül mihrâbına cem 'it İmâmeyn'i bu na 'tımla

Şeref kıble-nümâ-veş döne döne i 'tizârım var ( G.60/1-8)

Divanda geçen diğer tadadiye örnekleri şunlardır: ( G.102/3 ), ( Mes.3/1-30 ).

\section{Tazallüm/Şikayet}

Şikayet, sızlanma, yanıp yakınma anlamlarına gelir. Edebiyatta ise, şikayet, sızlanma ve yakınmaları içeren manzumelerin genel tarzını ifade etmektedir.

Mersiyeler bilindiği üzere bir nevi ölen kişinin medhiyesi olmakla birlikte, felekten şikayet ve yakınma tarzlarıyla tazallüm üslubunu da bünyesinde barındırmaktadır. Divanda mersiye türünde yazılmış 4. terkib-i bend, Bedri Bey isminde birinin eşinin vefatı dolayısıyla kaleme alınmıştır. 5 bend ve 30 beyitten oluşan bu mersiyenin 5 beyiti dua, 3 beyiti mehdiye, (bu beyitler aynı zamanda tazallüm tarzını da içinde barındırmaktadır) geriye kalan 22 beyiti ise felekten şikayet ve yerinme/yakınma tarzını ifade eden tazallüm tarzında yazılmıştır. Tazallüm esasen, arzıhal/hasbihal tarzının şikayet şeklinde yansıyan bir alt ünitesidir. 5. Tesdis bunun en güzel örneklerinden biridir. Şair bir taraftan felekten derd yanıp, şikayet ve yakınmalarını sunarken, diğer taraftan feleğe hitap ve serzenişleriyle felekle diyalog halindedir. Dolayısıyla bu şiir bir taraftan arzıhal/hasbıhal tarzını yansıtırken, diğer taraftan tazallüm/şikayet, tarzına örnek teşkil etmektedir. Özetle her tazüllüm/şikayet tarzı, aynı zamanda arzıhal/hasbıhal tarzını yansıtmakla beraber, her arzıhal/hasbıhal tarzı içinde tazallüm/şikayet tarzını barındırmayabilir. Şeref Hanım'ın gazel ve şarkılarının neredeyse tamamına yakın bir kısmında sevgili ile hasbihal vardır. Şair bu şiirlerde sevgili ile sohbet etmekte, gönlünü hoş ettiyse memnuniyetini ifade etmekte ama çoğu zaman ayrılık ve vefasızlıktan derd yanarak tazallüm/şikayet, yerinme tarzına bürünmektedir. Daha farklı bir yaklaşımla şair, bu şiirlerinde sevgilisi ile arasında geçenlerin günlüğünü tutmuştur denilebilir.

Mersiye türünde kaleme alınmış, "ağlamaz mısın" redifli 12. Kasidenin 1-7 arasındaki beyitlerde "ey dil, neler itdi ol pelîd, bilmez misin" gibi ifadelerle şair gönlünü muhatap almış; 816 arasındaki beyitlerde ise "ey Yezîd" ifadesiyle Yezîd'i muhatap alarak anlatım biçimi olarak hasbihali tercih etmiştir. Ey dil, ey gözüm hitaplarının bulunduğu 13. mersiyede, ey dîdelerim, ey gönül, yeter ey hâme( K. 13/6-15 ),felek, Şimr, İbn-i Ziyâd, ( K.14/1-25 ), ey“ zâlim ü gaddâr u sitem-kâr Yezîd, ( K.15/1-30 ), a felek, ibn-i Ziyâd kelbi, ey Şimr-i la‘în, ( K.16/1-39 ), ey Yezîd, ( K.17/1-42 ), ( K.18/1-43 ), (K. 19/3-9 ), ( K.21/7-16 ), gibi ifadelerin yer aldığı beyitler de tazallüm/şikayet tarzına örnek teşkil etmektedir.

Toldur devâtı iki gözüm hûn-ı eşk ile

Bu dem ne demdir eyle benimle refâketi (K.17/5)

Subha dek baht-l siyehle hasb-i hâl itdim bu şeb

Düşmene ey mâh-rû 'arz-ı melâl itdim bu şeb ( G.13/1)

Ol şâh-zâdegâna beyân eyle ey kalem

Ahvâl-i pür-melâlimi yaz söyleyim de ben (Tb.1/25) 
İdüp âzâr beni ol şûhh-ı cefâ-pîşe füzûn

Iltifâtıyla dili itmiyor aslâ memnûn

Tîğ-ı cevr ü elemi itmişs iken bağrımı hûn

Bir taraftan dahi sen itmedesin zâr u zebûn

Her dem ey tûb-l felek sîneme tokunma benim

Taş mı sandın yüreğim kal 'a mı sandın bedenim ( Ts.5/4)

Bu müdde 'a-yı felek olmadan hıtâma resîd

Kemâl-i ye's ile düşdüm yere çü berg-i hazân (K.21/14)

Olmuş idi seng-i mihnetle

Murg-ı emelin şikeste bâli

Gelse bile yok idi elemden

Gönlümde sürûra cây-ı hâlî

Indimde bir oldl fark olunmaz

'îd ile Muharrem'in hilâli

Gösterdi felek birer birer hep

Her mihneti bana lâ'ubâlî (K.23/3-6)

Gördüm nice bezm-i dil-güşâda

Akrânımı mesned-i safâda

Cürmüm nedir itmeyüp ifâde

Koydı dili cây-ı inzivâda

Kasdı felegin hemân banadır (Mh. 7/6)

Mislim cihanda Kays ile Ferhâd görmedi

Gönlüm ki kayd-l ye'sden âzâd görmedi

Çeşmi-i felek benim gibi ber-bâd görmedi

Bir kimse hâne-i dili âbâd görmedi

Kim gördi ise hâtırımı şâd görmedi

‘Ömrüm tükendi âh ki mihnet tükenmedi 
Nakd-i şekîb bitdi bu hasret tükenmedi ( G.252/1-5)

İdersin gönlümi vîrân dirsin yine âbâd it

İdüp bir kâseyi bin pâre yap kâbilse sultânım ( Kt.19/2 )

Divanda geçen diğer tazallüm/şikayet kayıtları şunlardır: ( K.2/6-11 ), ( K. 15/1-10), ( K.16/3-9 ), (Mr.1/1), (Mr.3/5), ( Mr.5/5 ), ( Mr.6/11-15 ), ( Mr.7/6-10 ), ( Mr.8/3-6 ), (Mh.1/8 ), (Mh.6/3 ), ( Mh.7/1-6 ), ( Mh.8/1-5 ), ( Th.1/1-5), ( Th.16/1 ), ( Ms.1/6-7, 9, 15 ), (Ms.3/1,4-5), ( Ms.10/1-4 ), ( Ms. 11/3 ), ( Ts.1/1-3 ), ( Ts.4/1-5 ), ( Ts.7/2-5 ), ( Ts.8/1-5 ), ( Ts.9/1-5 ), ( Msm.1/1-6 ), ( Tb.1/1-3 ), ( Tb.2/1,7-9, 13-14 ), ( Tb.3/1-29), ( Tc.1/1-3, 17-40 ), ( G.14/5 ), ( G.30/1 ), ( G.31/3 ), ( G.58/1-5 ), ( G.66/4 ), ( G.71/2 ), ( G.72/1-5 ), ( G.74/1-5 ), ( G.76/1-5 ), ( G.80/3 ), ( G.135/1-6 ), ( G.136/1-7 ), ( G.137/1-5 ), ( G.138/1-5 ), ( G.139/1-5 ), ( G.143/5 ), ( G.144/1-5 ), ( G.150/1-5 ), ( G.167/1-5 ), ( G.168/1-5 ), ( G.184/1-5 ), ( G.195/1-5 ), ( G.195/1-5 ), ( G.196/1-5 ), ( G.198/1-5 ), ( G.200/1-6 ), ( G.209/1-5 ), ( G.211/1-5 ), ( G.212/5-7 ), ( G.218/17 ), ( G.219/1-9 ), ( G.220/1-9), ( G.223/1-7 ), ( G.247/1-2 ), ( G.253/1-7), ( M.2/1-5 ), ( Ş.1/1-2 ), ( S..5/1-5 ), ( S..8/1-5 ), ( Ş.17/1-3 ), ( Ş.19/1-3 ), ( Ş.21/1-4 ), ( Ş.25/1-4 ), ( Ş.27/1-4 ), ( Ş.31/1-5 ), ( S..32/1-5 ), ( Ş.36/1-5 ), ( Ş.37/1-5 ), ( Ş.39/1-5 ), ( Ş.41/1-5 ), ( Kt.15/1-2 ), ( Kt.17/1-2 ), ( Kt.18/1-2 ), ( Kt.19/1-2 ), ( Kt.20/1-2 ), (Kt.24/1-2 ), ( Kt.44/1-2 ), ( Kt.54/1-2 ), ( Kt.67/1-2 ), ( Kt.69/1-2 ), ( Kt.79/1-2 ), ( Kt.82/1-2 ), ( Kt.85/1-2 ), ( Kt.88/1-2 ), ( Kt.95/1-2 ), ( Kt.97/1-2 ).

\section{Tel'in/Beddua}

Lanet okuma, lanetleme anlamlarına gelmektedir. Edebiyatımızda lanetleme içerikli bu şiirlere bir edebi tarz adını ifade edecek şekilde "tel'in" denilebilir. Divanda şair Yezid, Şimr ve İbn-i Ziyad'a lanetler okumaktadır.

İtmeyüp merdümek-i çeşm-i Resûl'e hürmet

Çıkasl gözlerini dikdi ne azlemdir bu (K.14/16)

Kurusun kopsun elin ayağın ey Şimr-i la î̀n

İki 'âlem dilerim başına zindân olsun (K.16/30)

Bu töhmet ile haşre kadar sana ey denî

Sebb ide cümle halk-ı cihân ağlamaz misın ～(K.12/16)

Eser-i nâlem ile bencileyin dünyânın

Ylkılup her tarafı ben gibi olsun vîrân (K.18/4)

Ben ölürsem yine la 'net okusun haşre kadar

Rûh-ı nâ-pâkinize hâk-i mezârım her ân (K.18/32)

Cigerim yakdı yeri âteş-i sûzân olsun

'Akl u fikrim gibi ahvâli perîşân olsun

Ba'd-ez-în kimse ne handân u ne şâdân olsun 
Dil-i zârım gibi dünyâ dahi virân olsun

Yakalar çâk iderek nâle vü feryâd idelim

Ylkalım 'âlemi bir âh ile ber-bâd idelim (Ms.15/2)

La'net hezâr la'net ola rûz u şeb revân

Hem sana hem sana uyan ahbâbina hemân

Divanda geçen diğer telin kayıtları şunlardır: ( K.16/30-31, 33 ), ( K.13/8-10), ( K.14/6, 16 ), ( K.16/1-2, 8-10 ), ( K.17/14, 21, 30 ), ( K.18/4-5, 17, 23, 28 ), ( K.19/4 ), ( K.20/11 ), ( Tb.1/7 ), ( Tc.1/6-8 ). Mersiye türünde kaleme alınan 4. müseddeste şiirin başından sonuna kadar telin tarzı ön plana çıkmaktadır.

\section{Tahmid}

Hamd etme, hamd kelimesini söyleme, şükretme anlamlarına gelmektedir. Tahmid metinleri, tevhit türünde tercih edilen bir anlatım biçimi (tarzı) olarak değerlendirilmektedir.

Bi-hamdillâh Muhammed Mustafâ gibi şehen-şâha

Bir ednâ ümmetim ki cihânda iftihârım var (G.60/2)

Senin ferrâşıı olmaklık dilerken Hakk'a hamd olsun

O devlet ölmeden oldı müyesser yâ Resûllâh (G.224/6)

Lâ-yu'ad hamd olsun ey gül pîrehen gördüm seni

Bülbül-i cânım kafesden uçmadan gördüm seni

Yok idi ümmîdim asla ölmeden gördüm seni

Minnet Allah'a efendim sağ esen gördüm seni (Ş.42/1)

Kerem-kârâ uzakdan görmeğe râzî iken zâtın

Bi-hamdillâh Hudâ takbîl-i dâmânin da gösterdi ( Kk.1/3)

Divanda geçen diğer tahmid metinleri şunlardır: ( Ş.42/1-5 ).

15. Tarih

Divanda vefat, doğum, evlenme, sünnet düğünü, sakal bırakma, kuran hıfz etme gibi çeşitli konularda yazılmış 122 adet tarih manzumesi bulunmaktadır. Şeref Hanım Divanı'ndaki tarihler tür ve tarz bakış açısıyla incelendiğinde oldukça zengin bir içeriğe sahip olduğu görülmektedir. Dolayısıyla bu kısımda, çalışmamızın sınırlarını aşacağı ve belki de başka bir çalışmanın konusu olabileceği için, sadece konuya dikkat çekilmek istenmiştir.

Hazret-i 'Abdü'l-Mecîd Hân'in Şeref itsün müdâm

Makdem-i ferzendini her vechile Allah sa îd

Dehre tebşîr eyledim târîh-i mîlâdın Şeref

"Müjdeler dünyâya geldi şimdi Şeh 'Abdü'l-Hamîd” (1258) (T.14/1-2)

\section{Tebrik}

Kutlama, tebrik içerikli manzumeler tebrik tarzını yansıtmaktadır.

Şeref ma'zursun ta'yîb olunmaz eyleme ârâm 
Bir iki beyt ile tebrîk-i câh eyle şetâretle ( Kk.5/5)

Bârekallâh letâfetde begim eş'ârın

Şu 'arâyı bu gidişle geçer inşâallah

( Kt.74/1)

\section{Teșekkür}

Şailerin mazhar olduğu bir ihsana karşılık yazdıkları teşekkür içerikli metinlere bir edebi tarz adını yansıtacak şekilde teşekkürname denilmektedir. 7. ve 59. gazel müstakil birer teşekkürnâme örnekleridir.

İtdi bir zât-ı kerem-ver ihdâ

Bana bir sübha olur cân-bahâ

...

Başla da'vâta teşekkürle Şeref

Rûzede mukbil olur çünki du'a (G.7/1,8)

Yok lutfuna 'add neyleyim kangı birini söyleyim

Nice teşekkür eyleyim hayretle oldum bî-karâr ( G.59/5)

Şehen-şehle cihân turdukça tursun mehd-i 'ulyâsı

Bana kendin de taltîfin de ihsânın da gösterdi ( Kk.1/1-5 )

Bir vech ile kâbil değil icrâ-yı teşekkür

Şâd oldı Şeref-zâr iki yüzden olun âgâh ( Kt.56/1-2 )

Divanda geçen diğer teşekkür kayıtları şunlardır: ( Kk.1/1-4 ), ( Kt.56/1-2 ), ( Kt.57/1-2 ), ( Kt.58/1-2 ).

\section{II- Edebi Türler \\ 1. Bahariye}

Baharla ilgili, bahara ilişkin anlamlarına gelmektedir. Edebiyatımızda bahar, bağ, bahçe, doğa, sabah tasvirlerine yer veren şiirlerin genel adıdır. 20.ve 22. kasideler bahariye türünde kaleme alınmıştır. 4. Şarkı da bahariye türüne örnek olarak gösterilebilir.

Buyur ey nahl-i işve mevsim-i geşt ü güzâr old $l$

Seninçün sahn-ı sînem dâğlarla lâle-zâr oldı

Ben itdikçe figân aşkınla bülbül şerm-sâr oldı

Açıl gül vaktidir ey gonca-fem fasl-ı bahâr oldı

Salın serv-i sehî-veş gülşene 'arz eyle reftârın

Sararsın reşk ile görsün de nergis çeşm-i hûn-hârın

Tağıt gî̀ûnı bilsin sünbül ü şeb-bû da mikdârın

Açıl gül vaktidir ey gonca-fem fasl-ı bahâr oldı (Ş.4/1-2)

Divanda geçen diğer bahariye örnekleri şunlardır: ( Kt.22/1-2 ).

\section{Besmelename}

Bismillah lafzının konu edildiği şiirlerin genel adıdır. 
Her umûrunda kim itse senedi bismillâh

Her dü-âlemde olur müstenedi bismillâh ( G.234/1)

Gerekdir evvelinde her umûrun yâd-1 bismillâh

Anı elzemdir itmek mutlakâ mu'tâd-1 bismillâh

Hatâdan ola sâlim dirsen eyle ibtidâ sen de

Şeref mecmû'a-i eş'ârına inşâd-1 bismillâh

( Kt.1/1-2 )

Divanda geçen diğer besmelename kayıtları şunlardır: ( G.234/1-5 ).

\section{Firakname/firkatname/hecrname}

Firak ayrılık anlamına gelmektedir. Firakname ise ayrılık konulu şiirlerin edebi bir tür adını yansıtacak şekilde genel adıdır. "Hicran-1 yâr" redifli 32. gazel, gel redifli 104. gazel, tiz gel redifli 109. gazel firaknamenin en güzel örneklerindendir. Firaknâmlerde anlatım biçimi olarak ayrılıktan şikayet, yakınma yerinme tarzlarını ifade eden tazallüm ön plana çıkmaktadır.

Yakdı cânım firâk-ı Hazret-i şeyh

El-amân âteş-i mahabbet-i şeyh ( G.26/1)

Lücce-i emvâc-ı fürkat mihnet-i hicrân-ı yâr

Başdan aşdı yok mı yâ Rab gâyet-i hicrân-ı yâr ( G.32/1)

Bir zamân bâde-i valsinla safâ-yâb oldı

Şimdi fürkatle gönül her dem ü her an ağlar (G.36/2)

Yârsız gönlüm açılmaz tutalım 'îd olmuş

Şeb-i fürkatde görülmez nice hurşîd olmuş

Mübtelâ-yl fürkatin şâyân-ı ihsân oldı gel

Çâre-sâzım haste-dil muhtâc-ı dermân oldı gel

Sanma eski mâ-cerâ şimdi firâkınla senin

Eşk-i çeşmimden benim tecdîd-i tûfân oldı gel (G.104/1,3)

Yalnızca bırakup derd-i firâkınla beni

Gitdin ammâ kerem it zülf-i kemendim tiz gel (G.109/3) 
Yakdı vücûd mülkini nâr-ı firâk-ı dost

Nitsin dil itmesin de figân âh âh âh ( G.222/3)

Lisânen söyleyim hâlim

Dahi gelmez misin zâlim

Yamân fürkatle ahvâlim

Dahi gelmez misin zâlim

Bahârın revnâkı gitdi

Hezârın nâlesi bitdi

Firâkın câna kâr itdi

Dahi gelmez misin zâlim

Yanından dûr u mehcûrum

Gam-ı fürkatle rencûrum

Yapılsın kalb-i meksûrum

Dahi gelmez misin zâlim (Ş.6/1-3)

Divanda geçen diğer firakname kayıtları şunlardır: ( G.36/1-5 ), ( G.105/2-3 ), ( G.127/4 ), ( G.132/1-5 ), ( G.146/4 ), ( G.175/6 ), ( G.176/1 ), ( G.221/1-5 ), ( G.222/1-5 ), ( SS.6/1-5 ), ( Kt.28/1-2 ), ( Kt.36/1-2 ), ( Kt.41/1-2 ), ( Kt.68/1-2 ), ( Kt.78/1-2 ).

\section{Kudumiye}

Sözlük anlamı itibariyle uzak yoldan gelen bir din ya da devlet büyüğüne sunulan armağan demektir. Edebiyatta ise bu amaçla sunulan şiirlere denilmektedir. Divanda 23. kaside kudumiye türünde kaleme alınmıştır.

Íslambol'a oldl sâye-endâz

Ol bâ̆ğ- 'inâyetin nihâli

Teşrif idince içlilikten

Karşıladılar o nîk-fâli

Çün âb-ı hayât bu sûya akdı

Ol çeşme-i kulzümün zülâli

Yümn-i kademiyle ben de itdim

Takdîme cesâret 'arz-ı hâli 
Çınlatdı girince gûş-ı câna

Billâh bu müjdenin me'âli

Hoş geldin eyâ Mesîh-i devrân

İhyâya bu kalb-i pür-melâli （K.23/25-30)

\section{Mektup}

Divanda mesnevi nazım şekliyle kaleme alınmış iki adet mektup bulunmaktadır.

Eser-i nâmene rûzân u şebân

İntizâr üzre iken nice zamân

Hamdü-lillâh ki bir vakt-i sa îd

Geldi mektûbun ile şevk-i cedîd

Eylemişsin bana ey tab'- z zarîf

Üsküb'ün tavr-l 'acîbin ta 'rîf

Yine mektûbun ile yâd idesin

Şeref'in gönlüni âbâd idesin (Mes.4/7-9,16)

Nicesin zevk ile ülfetde misin

Nicesin gûşe-i sihhatde misin

Beni hasretle buraktın gitdin

İstiyâkın ile haste itdin

Fürkâtin hâlimi itdi ber-bâd

Kulunı sen de ider misin yâd

$\ldots$

Cümle ahbâb ile rûzân u şebân

Zikrini itmedeyiz vird-i zebân

$\cdots$

İşte pâyâna irişdi mektûb

İderim lîk cevâbın matlûb $\quad$ (Mes.5/2-4,9,13)

\section{Mersiye}

Divanda 20 adet mersiye bulunmaktadır. Bunlardan 16's1 kerbela mersiyeleridir. $\mathrm{Bu}$ çalışmada mersiyeler anlatım biçimleri (tarz) açısından değerlendirilmiştir. 


\section{Mevlid}

Kelime manası doğmaktır. Edebiyatımızda Hz. Peygamber'in doğumunu anlatan metinlere bir edebi tür adını ifade edecek şekilde mevlid denilmektedir. Şeref Hanım "Kıt'a Berây-1 Şeb-i Mevlidü'n-Nebî” başlığıyla mevlid türüne örnek olabilecek sadece bir manzume kaleme almıştır.

Nic'olur kadrde hiç Kadr'e berâder bu gice

Oldı Hakk'in kerem ü lutfina mazhar bu gice

R̂िz-ı a yâda müreccâh nola fahr eyler ise

Togdı bi'z-zât şehen-şâh-ı Peyember bu gice ( Kt.5/1-2 )

\section{8. $\quad$ Naat}

Divanda 21 adet naat bulunmaktadır. Bu çalışmada naatlar anlatım biçimleri (tarz) açısından değerlendirilmiştir.

\section{Sakiname/İşretname/Sahbaname}

Saki, su veren, içki sunan anlamlarındadır. Edebiyatımızda ise, genellikle içki dağıtıcısı olarak sakiye seslenen, içkiyi ve saki anlatan/öven şiirlere sakiname denilmektedir. Divanda müstakil sakiname örneğine rastlanmamakla birlikte, beyit bazında sakiname türüne örnek verilmiştir.

Ben şarâb-ı ye's ile mest ü harâbım sâkiyâa

Gayre sun sen sâgar-ı pür-neş'eyi şimden geri ( K.19/3)

Hırmen-i sabrım tutuşdı bir takım eşrâr âh

Koydı susuz zâde-i Sâkî-i havz-ı Kevser'i ( K.19/5)

Yok minnetimiz sâgar-ı gül-gûnuna sâkî

Mest itdi bizi bâde-i hamrâ-yı mahabbet ( G.23/3)

Girdi elime ayag-ı sâkî

Oldum yine ben çerâğ-ı sâkî

Destûr-l şehen-şeh-i gam olsun

Kim dinler o dem yasag-ı sâkî ( Kt.16/1-2 )

Divanda geçen diğer sakiname kayıtları şunlardır : ( G.37/1 ), ( G.56/2 ), ( G.85/5 ), ( G.114/1 ), ( G.171/1 ), ( G.172/1-2 ), ( G.179/6), ( G.182/3 ), ( G.241/1 ), ( G.251/2 ), ( S..1/3 ), ( Ş.10/1 ), ( Ş.11/2).

\section{Salname}

Sal, yıl, sene anlamına gelmektedir. Salname ise, yıllık olmak üzere belirli mevzularda kaleme alınan manzumelerin adıdır. Divandaki bütün kerbela mersiyeleri aynı zamanda bir salname özelliği taşımaktadır. Şair bu mersiyeleri her yıl muharrem ayı gelince kaleme almakta ve ömrü oldukça her yılın muharrem ayında bir kerbela mersiyesi yazmaya ahd etmektedir. Dolayısıyla bu mersiyeler yılda bir çıkan yazı niteliğiyle salname olarak da değerlendirilebilir. 
Muharrem 'dir yine derd-i nihânım âşikâr olsun

Muharrem'dir yine kârım hemîşe âh u zâr olsun (K.13/1)

Muharrem'dir yine dâg-ı derûnum eyledim izhâr

Muharrem'dir yine ağzımdan âteşler nisâr olsun (K.13/2)

Muhibb-i âl ü evlâd-ı Resûl-ı müctebâyım ben

Bana her sâl bir mersiye inşâdı şi 'âr olsun (K.13/13)

Yine yıkdı başıma çarh-ı felek dünyâyı

Zevk u şevk ile bana ba'd-ez-în ülfet mi olur

Her sene tâzelenür dilde onulmaz yârem

Zahmıma merhem-i Lokmân ile sihhat mi olur (K.15/3)

Yılda bir mâh-ı Muharrem diyerek dâğ-ı dili

'Arz ider arz u semâ ketme liyâkat mi olur

Itddi zuhûr yine hilâli Muharrem'in

Geldi derûna hayf Yezîd'in hikâyeti (K.17/4)

\section{Tehlil}

Klasik Türk şiiri içinde lâ ilâhe illallah veya lâ ilâhe illa Hû zikirlerini redif olarak kullanan, bu zikrin övgüsü ve tavsiyesinde bulunan metinlere bir tür adına ifade edecek şekilde tehlil denilebilir. Divandaki kaside nazım şekliyle yazılmış 15 beyitlik ilk şiir tehlil türünde kaleme alınmıştır.

Gubâr-ı kalbi siler lâ ilâhe illallah

Komaz gönülde keder lâ ilâhe illallah (K.1/1)

Eğerçi var ise 'aklın başında ey dil ola

Dilinde şâm u seher lâ ilâhe illallah (K.1/2)

$\cdots$

Ne dem kazâdan emîn olmak ister isen ĕger

Olur o anda siper lâ ilâhe illallah (K.1/5)

\section{Sonuç}

Şeref Hanım Divanı birçok edebi tür ve tarzı bünyesinde barındıran, muhteva ve üslup açısından hayli zengin bir metindir. Öyle ki bazen birden çok tür ve tarzın bir şiirde işlendiği görülmektedir. Bazen de bir bend ya da beyitte birden fazla tarza rastlanmaktadır. Yalnız şunu belirtmeliyiz ki, bu durum karışıklığa yol açmamakla birlikte, edebi tür ve tarzların uyum içinde iç içe geçebildiğine, dahası onların klasik şiirimiz çerçevesinde en küçük nazım birimleri seviyesinde dahi aranabileceğine işaret etmektedir. Diğer taraftan, Şeref Hanım Divanı'ndaki bu edebi tür ve 
tarz zenginliği, göz ardı edilen tarzların, belki hatta türlerin gün yüzüne çıkarılması, üzerinde tartışılması gerektiğinin vesikası olsa gerektir.

\section{Kaynakça}

Açıl, B. (2014). Bir Tür mü Tarz mı? Klasik Türk Edebiyatında Alegori. Divan Disiplinlerarası Çalışmalar Dergisi, 19(37): 145-167.

Akkuş, M. (2007). Klasik Türk Şiirinin Anlam Dünyası: Edebi Türler ve Tarzlar. Fenomen Yayınları.

Akkuş, M. (2009). Şeyh Galib'in Anlam Dünyası: Hüsn ü Aşk'ta Edebi Türler ve Tarzlar. Turkish Studies, Volume 4(7): 97-112.

Arslan, M. (2011). Şeref Hanım Dîvânı. Kitabevi Yayınları.

Aydın, A. (2016). Klasik Türk Şiirinde Levendane Tarz. Erdem Dergisi, 70: 5-23. "https://doi.org/10.32704/erdem.536801"

Aykanat, T. (2012). Fuzûlî’nin Leylâ vü Mecnûn Mesnevîsinden Hareketle Edebî Metnin Üç Kilit Noktası Üzerine: Tür, Tarz ve Teknik. Jass, Volume 5(7): 137-162. "https://doi.org/10.17719/jisr.2017.1635"

Aykanat, T. (2013). Cevrî Dîvân'ı Örnekçesinde Edebî Türler ve Tarzların Metin Kurulumundaki Rolü”. A. Ü. Türkiyat Araştırmaları Enstitüsü Dergisi (TAED), Erzurum, 50: 47-67. "https://doi.org/10.14222/turkiyat13"

Çalka, M.S. (2014). Tür ve Tarz Çeşitliliği Açısından Zengin Bir Divan: Süheylî Divanı. Turkish Studies, Volume 9(3): 423-450. "https://doi.org/10.7827/turkishstudies.6199"

Dilçin, C. (2013). Örneklerle Türk Şiir Bilgisi. Türk Dil Kurumu Yayınları.

Ece, S. (2015). Klasik Türk Edebiyatı Araştırma Yöntemleri I-II. Eser Basım Yayınları. "https://doi.org/10.14222/turkiyat1488"

İsen, M. (1994). Acıyı Bal Eylemek Türk Edebiyatında Mersiye. Akçağ Yay.

Kardaş, S. (2013). Cem Sultan'ın Cemşîd ü Hurşîd Mesnevisinin Edebi Tarzlar Açısından Değerlendirmesi. Turkish Studies - International Periodical For The Languages, Literature and History of Turkish or Turkic, Volume 8(1): 1899-1909. "https://doi.org/10.7827/turkishstudies.4532"

Tanrıbuyurdu, Gülçin (2015). Klasik Türk Şiirinde Kadın Söyleminin İzinde: Şeref Hanım Divanı'nda Ninniler. Insan ve Toplum Bilimleri Araştırmalart Dergisi, 4(1): 112-120. "https://doi.org/10.15869/itobiad.55619" 